\title{
Petrology and geochemistry of granitic rocks in Dan Chang area, Suphan Buri Province, Central Thailand: Implication for petrogenesis
}

\author{
Thirawat Tukpho ${ }^{\mathrm{a}}$, Alongkot Fanka ${ }^{\mathrm{b}, *}$ \\ a Department of Geology, Faculty of Science, Chulalongkorn University, Bangkok 10330 Thailand \\ b Applied Mineral and Petrology Special Task Force for Activating Research (AMP STAR), Department of \\ Geology, Faculty of Science, Chulalongkorn University, Bangkok 10330 Thailand
}

*Corresponding author, e-mail: alongkot.f@chula.ac.th

Received 4 Feb 2021

Accepted 6 Jun 2021

\begin{abstract}
Triassic granitic rocks exposed in Dan Chang area are northern and southern granitic units. These granites intruded Silurian-Devonian clastic sedimentary rocks of Bo Phloi Formation and Ordovician limestones of Thung Song Group. Fifteen representative samples were collected for petrography, whole-rock geochemistry, and mineral chemistry studies. These granites show porphyritic texture and comprise quartz, K-felspar, plagioclase, biotite, and muscovite as the major compositions, with the minor compositions of ilmenite, zircon, and apatite. Moreover, aplite and pegmatite are associated with the southern granite as dikes. Aplite and pegmatite are composed of mainly K-feldspar, quartz, tourmaline, and plagioclase. Based on the whole-rock geochemistry, these rocks can be classified as peraluminous S-type granite to granodiorite, originating from high-K calc-alkaline and derived from an upper crustal source. The geotectonic discrimination diagrams show that these granitic rocks are significantly related to syn-collision to late-orogenic. The mineral chemistry of the granites shows a close relationship of their compositions and magma genesis, which can imply that aplite might be the last stage of the granitic crystallization. Moreover, the crystallization Pressure-Temperature (P-T) conditions of the northern and the southern granites are $3.4-3.7 \mathrm{kbar}, 571-630^{\circ} \mathrm{C}$ and $3.3-3.8 \mathrm{kbar}, 624-656^{\circ} \mathrm{C}$, with calculated intrusion depths of $12-13 \mathrm{~km}$ and $12-14 \mathrm{~km}$, respectively. These granitic rocks are comparable to the S-type granite of the Central Belt Granite of Thailand, resulted from syn-collisional crustal thickening and subsequent post-collision after the closure of the Paleotethyan during the Late Triassic.
\end{abstract}

KEYWORDS: S-type granite, petrology, geochemistry, P-T condition, Thailand

\section{INTRODUCTION}

The granitic rocks in Thailand and Southeast Asia have been studied with respect to geological setting, lithology, geochemistry, and geochronology by numerous researchers [1-5]. Particularly in Thailand, the granitic rocks can be divided into Eastern Belt, Central Belt, and Western Belt $[4,6]$. The Eastern Belt Granite (EBG) was formed during Late Carboniferous to Late Triassic [4,6-9]. Central Belt Granite (CBG), which covers most of Thailand, was formed in Late Triassic to Middle Jurassic $[4,6,10]$. The Western Belt Granite (WBG), the smallest mass of granite belt in Thailand, found along ThailandMyanmar border, was formed in Late Cretaceous to Early Tertiary $[4,6]$.

The CBG occupies about three-fourths of the granitic terrains from Chiang Rai, Chiang Mai, and Lampang in the North to Tak and Uthaithani in the
Central Plain and Rayong in the East and Eastern part of the Peninsular area [4-6]. The granitic rocks in the $\mathrm{CBG}$ are very complicated and can be divided into foliated granite, megacrystic biotite granite, and alkaline complex $[4,5]$. For the lithology of these granites, biotite granite and muscovitebiotite granite are dominant phases, while hornblende granite is rare [4]. The granitic rocks in the CBG have been reported as porphyritic coarsegrained granite with abundant biotite, muscovite, equal amounts of quartz and feldspar, and a lack of green hornblende $[3,11]$. According to previous studies, the CBG has been interpreted as the S-type or ilmenite-series granitoids originated from partial melting of the crust $[12,13]$.

Although the granitic rocks in CBG have been reported in many areas, especially in the NW of Thailand and the SE of the Thai Peninsula, there are few studies on petrology and geochemistry of 
the CBG in Central Thailand, especially in the Dan Chang area, Suphan Buri Province. Thus, the study on petrography, mineral chemistry, and geochemistry of the granitic rocks and related intrusive rocks of the Dan Chang District, Suphan Buri Province located in the west of Central Thailand can lead to better understanding of the magmatism and tectonic setting of the studied area.

\section{GEOLOGICAL BACKGROUND}

In the Dan Chang area, Suphan Buri Province, Central Thailand (Fig. S1a), there are three rock units [14], including Ordovician Thung Song Group, Bo Phloi Formation, and igneous rocks (Fig. S1b). The Ordovician Thung Song Group consists of dark grey and grey, thick-bedded and massive limestones, argillaceous limestone, dolomitic limestones, partly metamorphosed limestones, and marble. The bedding trend of these rocks is NE-SW. The SilurianDevonian Bo Phloi Formation is mainly clastic sedimentary rocks, including siltstone and shale interbedded with grey, reddish-brown, fine- to coarsegrained, subrounded, well-sorted quartzitic sandstone and lithic sandstone, and metamorphic rocks of quartzite, phyllite. The trends of the beddings are mainly NE-SW and NW-SE. The main joint directions of these rocks are NE-SW and NW-SE [14] and run through granitic rocks in this area. For the igneous rocks, referred to as Triassic granites [14], fine to coarse-grained quartz, feldspar, biotite, or muscovite granite, and porphyritic granite can be found with associated quartz and pegmatite veins (Fig. S1b). The granitic rocks in this area are located in the CBG trending $[4,6,15-17]$ as shown in Fig. S1a.

\section{METHODOLOGY}

Fifteen representative samples were collected from ten locations of the studied area (Fig. S1b). All samples were prepared as polished-thin section studies by grinding powder no. 600, 1000 and 6, 3, micron of diamond paste, respectively, for petrographic study using a Polarized light microscope. Powdered samples were prepared by disc mill and dried at $105^{\circ} \mathrm{C}$ for $2 \mathrm{~h}$. Whole-rock geochemical analyses for major and minor compositions of the representative samples were carried out by an Xray Fluorescence Analyzer (XRF), model Bruker AXS S4 Pioneer at the Department of Geology, Faculty of Science, Chulalongkorn University (CU). The major and minor oxides $\left(\mathrm{SiO}_{2}, \mathrm{TiO}_{2}, \mathrm{Al}_{2} \mathrm{O}_{3}, \mathrm{FeO}_{\mathrm{t}}, \mathrm{MnO}\right.$, $\mathrm{MgO}, \mathrm{CaO}, \mathrm{Na}_{2} \mathrm{O}, \mathrm{K}_{2} \mathrm{O}$, and $\mathrm{P}_{2} \mathrm{O}_{5}$ ) were analyzed according to international rock standards (BHVO-2,
JG-2, RGM-1, AGV-2, GSP-2) for calibration. Loss on ignition (LOI) was also measured prior to XRF analysis by weighing one gram of dried powdered samples before and after heating at $1050^{\circ} \mathrm{C}$ for $3 \mathrm{~h}$. Moreover, trace elements and REE compositions of the representative samples were performed by an Inductively Coupled Plasma-Mass Spectroscopy (ICP-MS) at ALS with detection limits ranging from $0.0004 \mathrm{ppm}$ to $0.01 \%$ for trace elements. Hydrofluoric acid and nitric acid were used to digest the rock samples and the rock standards [18]. Polished thin sections were analyzed for mineral chemistry using an Electron Probe Micro-Analyzer (EPMA), model JEOL JXA-8100, at the Department of Geology, CU with the analytical condition at $15 \mathrm{kV}$ and about $2 \mu \mathrm{A}$ for focused beam spot $(1 \mu \mathrm{m})$. Mineral standards and pure oxides were used to calibrate at the same condition with automatic ZAF correction and weight percent oxides reporting.

\section{RESULTS}

\section{Field Sampling and petrographic description}

The granitic exposures in the studied area can be classified into two units: the southern (main) and the northern (small) granitic units (Fig. S1b). These granites are characterized by porphyritic granite with abundant K-feldspar as phenocrysts and groundmass, where the ratio of phenocryst and groundmass is about $60: 40$, and other minerals including quartz, biotite, and muscovite (Fig. 1a-d). Moreover, pegmatite and aplite are usually associated with the southern granite unit (Fig. 1c).

For the granites in the northern unit, major mineral assemblages are K-feldspar and microcline (35-40\%), quartz (30-35\%), plagioclase (5-10\%), biotite (10-15\%), and muscovite (5\%). K-feldspar $(1 \mathrm{~mm}-5 \mathrm{~cm})$ shows perthitic texture as subhedral to euhedral phenocrysts. For other compositions, anhedral to subhedral quartz $(0.25-1 \mathrm{~mm})$, anhedral to subhedral of plagioclase $(0.25-1 \mathrm{~mm})$ with albite twinning, subhedral to euhedral microcline $(0.25 \mathrm{~mm}-1.5 \mathrm{~cm})$ with cross-hatched twinning, subhedral to euhedral biotite $(0.25 \mathrm{~mm}-3 \mathrm{~cm})$, and muscovite $(0.25 \mathrm{~mm}-1 \mathrm{~cm})$ are commonly presented together with accessory minerals (up to 1\%) of zircon, apatite, and opaque minerals.

The southern unit is largely composed of granite and associated pegmatite and aplite dikes. Petrographic description of the southern unit is displayed as follows.

The southern granite unit comprises K-feldspar (40-45\%), quartz (35-40\%), plagioclase (10- 

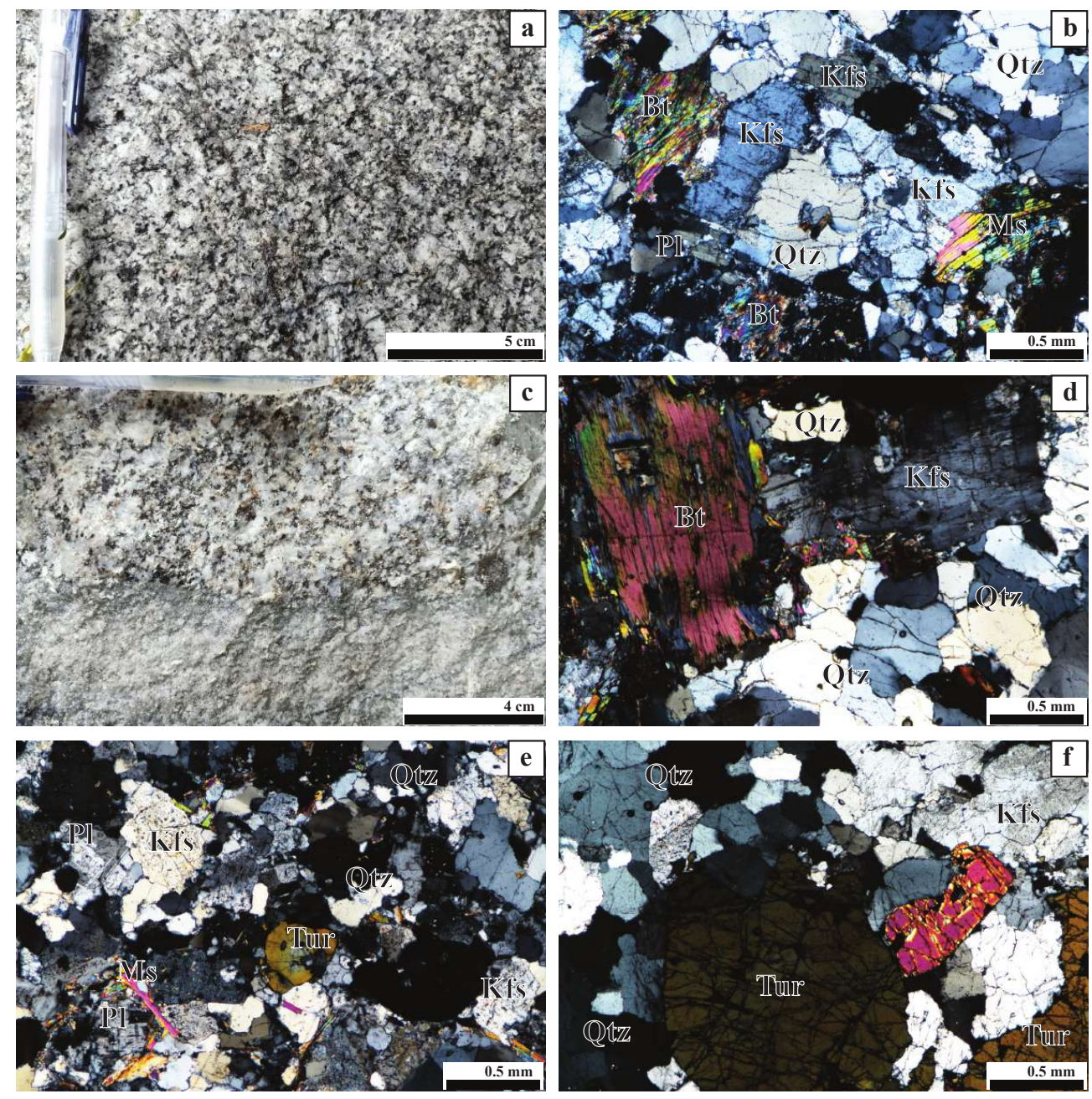

Fig. 1 (a) The porphyritic texture of K-feldspar of granite in location number 4 located in the northern unit; (b) the photomicrograph under cross-polarized light (XPL) of the granite in the northern unit showing the main mineral assemblages; (c) the porphyritic texture of K-feldspar of granite in location number 8 located in the southern unit and associated aplite; (d,e,f) the photomicrograph under XPL of the granite in the southern unit, aplite, and pegmatite, respectively. Abbreviations: Qtz (quartz); Kfs (K-feldspar); Bt (biotite); Pl (plagioclase); Ms (muscovite); Tur (tourmaline).

$15 \%$ ), biotite (5-10\%), and less abundant muscovite (2-3\%). Euhedral to subhedral K-feldspar phenocrysts $(1 \mathrm{~mm}-6 \mathrm{~cm})$ generally show perthitic texture and poikilitic texture. Subhedral to anhedral quartz $(0.5-2 \mathrm{~mm})$, anhedral to subhedral plagioclases $(0.25-1 \mathrm{~mm})$ with clear albite twinning, subhedral to euhedral biotite $(2 \mathrm{~mm}-3 \mathrm{~cm})$, and muscovite $(0.25 \mathrm{~mm}-1.5 \mathrm{~cm})$ are by and large observed. Accessory minerals such as zircon, apatite, and opaque minerals are commonly discovered in all thin sections.

Aplites are exhibited as dikes injected into the southern granite. Mineral assemblages of aplite are mainly quartz (40-45\%), K-feldspar (25-30\%), tourmaline (10-15\%), plagioclase (5-10\%), and muscovite (1-2\%), but no biotite. Generally, quartz, K-feldspar, and plagioclase show phaneritic texture. Moreover, fine-grained quartz and K-feldspar are sometimes found in tourmaline as poikilitic texture (Fig. 1e).

Pegmatite dikes are common in the southern granite. They consist of K-feldspar (45-50\%), quartz (25-30\%), tourmaline (25-30\%), plagioclase (1-2\%), and muscovite (1-2\%). These mineral assemblages are mostly coarse-grained (1$3.5 \mathrm{~cm}$ ), especially tourmaline and K-feldspar. How- 


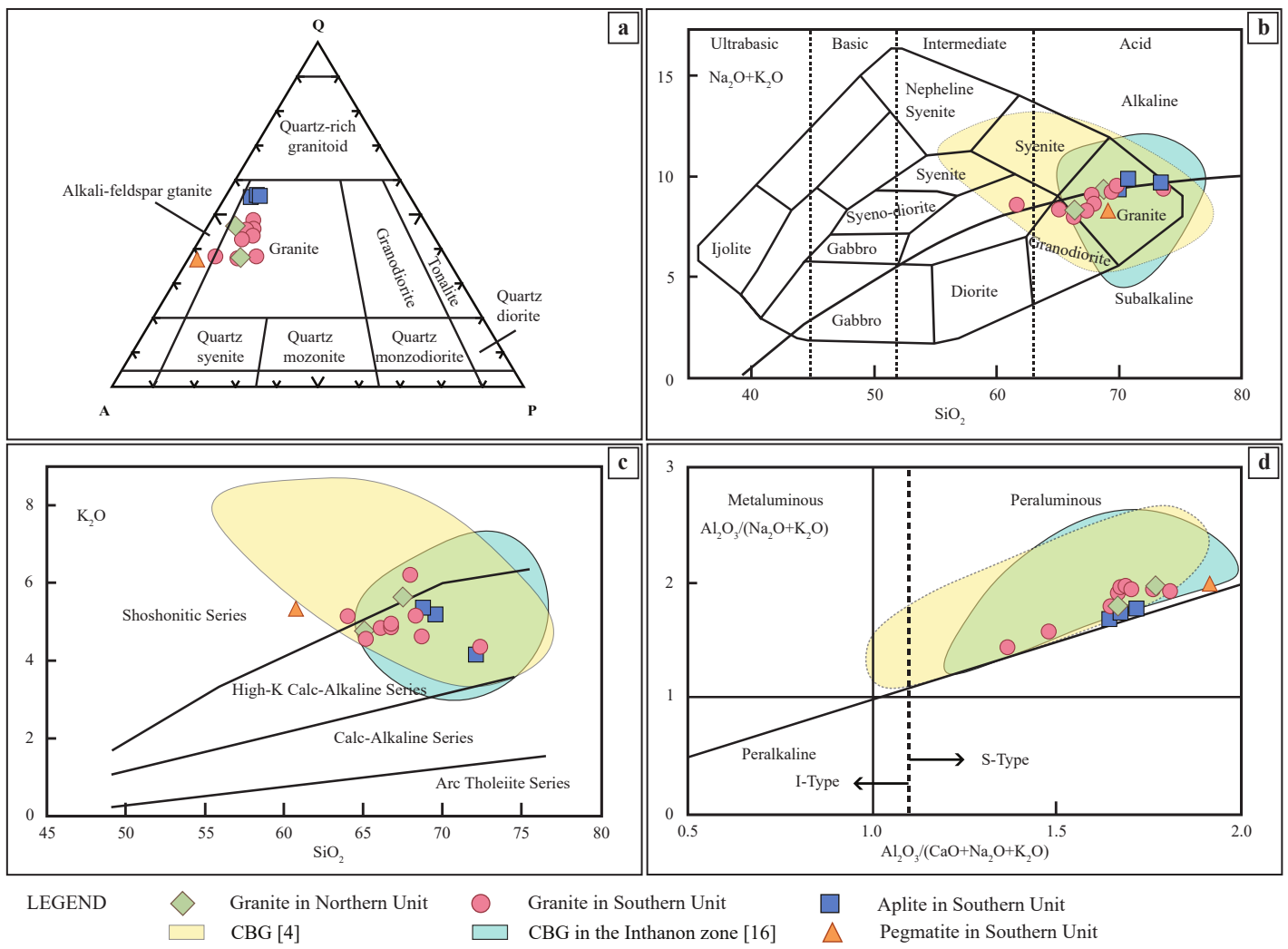

Fig. 2 (a) QAP classification of plutonic rocks; (b) discrimination diagram of plutonic rock [19]; (c) the plots of $\mathrm{SiO}_{2}$ against $\mathrm{K}_{2} \mathrm{O}[20,21]$; (d) the plot of $\mathrm{Al} /(\mathrm{Ca}+\mathrm{Na}+\mathrm{K})$ against $\mathrm{Al} /(\mathrm{Na}+\mathrm{K})$ [22]. The yellow shade and blue shade (Inthanon zone) of the CBG were from data reported by $[4,16]$.

ever, fine-grained quartz $(0.22-0.5 \mathrm{~mm})$ and plagioclase $(0.1-0.25 \mathrm{~mm})$ are also present (Fig. 1f). Based on the modal QAP classification of plutonic rocks, all samples can be classified as granite, except the pegmatite, which was classified as alkalinefeldspar granite (Fig. 2a).

\section{Whole-rock geochemistry}

Whole-rock geochemistry data from the representative samples from both granitic units including two samples from the northern granitic unit and thirteen samples from the southern granitic unit are summarized in Table S1. Based on the major and minor compositions, all granites from both northern and southern units show similar compositions of the granites and related rocks. For example, $\mathrm{SiO}_{2}$ of 66.27-68.62 wt $\%$ and 61.73-73.59 $\mathrm{wt} \%$; and $\mathrm{Al}_{2} \mathrm{O}_{3}$ of $16.44-17.06 \mathrm{wt} \%$ and $13.68-17.95 \mathrm{wt} \%$ are for the northern unit and the southern unit, respectively. Moreover, the rocks from both units show high potassium content (4.26-5.73 $\mathrm{wt} \%$ of $\mathrm{K}_{2} \mathrm{O}$ ) and high $\mathrm{Na}_{2} \mathrm{O}+\mathrm{K}_{2} \mathrm{O}$ content (8.01-9.97 wt\%). The TAS diagram plot of $\mathrm{SiO}_{2}$ against $\mathrm{Na}_{2} \mathrm{O}+\mathrm{K}_{2} \mathrm{O}$ [19] shows that these rocks are mainly granite with some granodiorite compositions (Fig. 2b). For the plot of $\mathrm{K}_{2} \mathrm{O}$ versus $\mathrm{SiO}_{2}$ diagram [20,21], these rocks are mainly high-K calc-alkaline to shoshonitic series (Fig. 2c). The plot of $\mathrm{Al} /(\mathrm{Ca}+\mathrm{Na}+\mathrm{K})$ against $\mathrm{Al} /(\mathrm{Na}+\mathrm{K})$ [22] shows that these rocks are peraluminous S-type granite (Fig. 2d). Harker variation diagrams of $\mathrm{SiO}_{2}$ versus other oxides [23] show mostly scattered distributions $\left(\mathrm{Al}_{2} \mathrm{O}_{3}, \mathrm{FeO}_{\mathrm{t}}, \mathrm{MgO}, \mathrm{MnO}, \mathrm{K}_{2} \mathrm{O}\right)$ with some negative correlations between $\mathrm{TiO}_{2}$ and $\mathrm{CaO}$ and positive correlation of $\mathrm{Na}_{2} \mathrm{O}$ from granite to pegmatite and aplite (Fig. 3).

Primitive mantle-normalized spider diagrams (Fig. 4a) of the rocks reveal similar patterns of the marked $\mathrm{Ba}, \mathrm{Nb}$, Ti deletion, $\mathrm{Rb}, \mathrm{Th}, \mathrm{K}$, and $\mathrm{Pb}$ enrichments. The chondrite-normalized REE patterns with chondrite-normalized $\mathrm{La} / \mathrm{Yb}$ ratios from 1.87 to 10.49 are shown in Fig. $4 \mathrm{~b}$. The REE patterns reveal slight enrichment from LREE to HREE, with the marked Eu negative (Fig. 4b). These primitive mantle-normalized spider diagrams (Fig. 4a) and chondrite-normalized REE patterns (Fig. 4b) (primitive mantle and chondrite values from [24]) are 

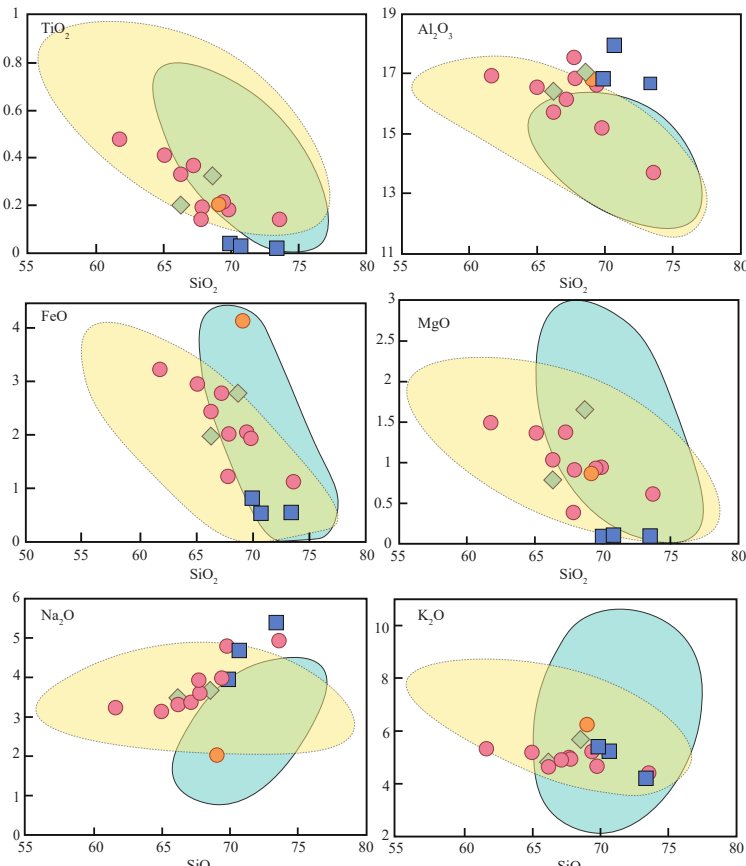

LEGEND $\bigcirc$ Granite in Southern Unit $\diamond$ Granite in Northern Unit $\square$ Aplite in Southern Unit Pegmatite in Southern Unit $\square$ CBG [4]

$\square$ CBG in the Inthanon zone $[16$

Fig. 3 Harker variation diagrams [23] with yellow shade and blue shade (Inthanon zone) of the CBG from reported data $[4,16]$.

comparable to syn-collisional granite [25] and the upper crust pattern [26].

\section{Mineral chemistry}

Mineral chemistry analyses of biotite, feldspar, and opaque minerals were carried out, and the results are summarized in the Supplementary Data.

Biotite: Biotite in the southern and northern granites shows similar aluminum (Al) content (about $1.4 \mathrm{pfu}$ ) but with slightly higher $\mathrm{TiO}_{2}$ and $\mathrm{FeO}_{\mathrm{t}}$ contents in the former $(2.34-2.86 \mathrm{wt} \%$ of $\mathrm{TiO}_{2}, 20.21-20.96 \mathrm{wt} \%$ of $\mathrm{FeO}_{\mathrm{t}}$ ) than in the later $\left(1.80-2.42 \mathrm{wt} \%\right.$ of $\mathrm{TiO}_{2}, 20.08-20.93 \mathrm{wt} \%$ of $\left.\mathrm{FeO}_{\mathrm{t}}\right)$. In addition, biotite cannot be found in the aplite. These biotite minerals are classified into annitesiderophyllites based on the classification of [27]. The summary of the mineral chemistry of biotite is shown in Table S2.

Feldspar: Plagioclase and K-feldspar are presented in Tables S3 and S4, respectively. Plagioclase in the southern unit reveals the anorthite (An) contents from 10-13, classified as oligoclase. Moreover, both granite and aplite in the northern unit show similar An-contents of plagioclase as albite $\left(\mathrm{An}_{0-8}\right.$ in granite; $\mathrm{An}_{0-1}$ in aplite). K-feldspar in the northern
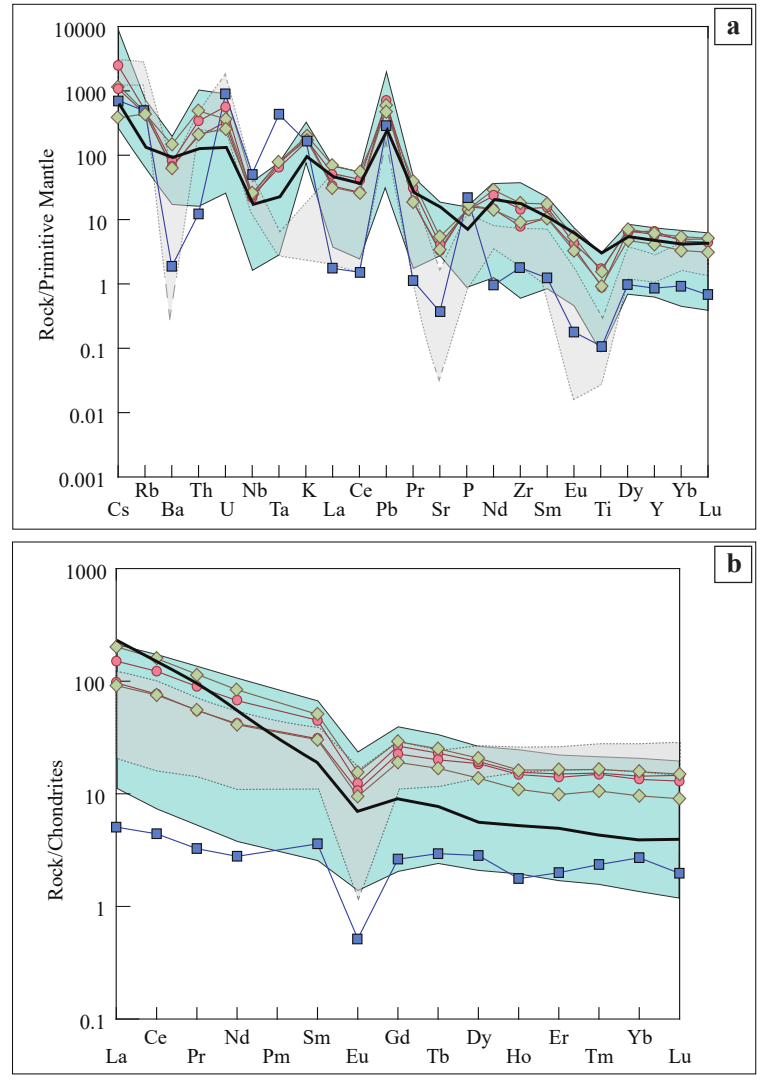

LEGEND $\odot$ Granite in Southern Unit $\diamond$ Granite in Northern Unit - Upper crust [26] $\square$ Aplite in Southern Unit $\square$ Syn-collisional granite [25] $\square$ CBG in the Inthanon zone [16]

Fig. 4 (a) Primitive mantle-normalized spider diagram (primitive mantle values from [24]; (b) chondritenormalized REE patterns (chondrite values from [24] of the studied rocks compared with the upper crust of Earth [26]), syn-collisional granite [25], and in the Inthanon zone [16].

granite $\left(\mathrm{Or}_{91-100}\right)$ is the same as the southern granite $\left(\mathrm{Or}_{90-94}\right)$ which can be classified as orthoclase.

Opaque minerals: Opaque minerals are usually found as accessory minerals. Based on the mineral chemistry, these opaque minerals are ilmenite in all units and composed of 42.17-42.59 $\mathrm{wt} \% \mathrm{FeO}_{\mathrm{t}}$ and $50.26-51.68 \mathrm{wt} \% \mathrm{TiO}_{2}$. The mineral chemistry of ilmenite is shown in Table S5.

\section{DISCUSSION}

\section{Crystallization P-T condition and intrusion depths}

In terms of pressure of crystallization, the Al-in biotite geobarometer of [28] was effectively used to estimate the crystallization pressure $(\mathrm{P})$ of the granitic rocks by following the equation: $\mathrm{P}$ (kbar) 
$=3.03 \times \mathrm{Al}-6.53( \pm 0.33)$, where $\mathrm{Al}$ is the total alumina per formula unit calculated on the basic of $\mathrm{O}=22$. In this study, the calculated pressures of the southern and the northern granites are similar ranging from 3.32 to $3.76 \mathrm{kbar}\left(\mathrm{P}_{\mathrm{avg}}=3.55 \mathrm{kbar}\right)$ and 3.36 to $3.67 \mathrm{kbar}\left(\mathrm{P}_{\mathrm{avg}}=3.54 \mathrm{kbar}\right)$, respectively (Table S2).

For crystallization temperature, it is calculated by using Ti-in biotite geothermometer of [29] and the geothermometric expression: $\mathrm{T}=\{[\ln (\mathrm{Ti})+$ $\left.\left.2.3594+1.7283\left(\mathrm{X}_{\mathrm{Mg}}\right)^{3}\right] / 4.6482 \times 10^{-9}\right\}^{0.333}$, where $\mathrm{T}$ is the temperature in degrees Celsius, $\mathrm{Ti}$ is the number of atoms per formula unit (apfu) on the basic of $\mathrm{O}=22$ atoms, and $\mathrm{X}_{\mathrm{Mg}}$ is $\mathrm{Mg} /(\mathrm{Mg}+\mathrm{Fe})$. Based on the calculation results, the crystallization temperatures of the southern body granite, ranging $623.98-655.43^{\circ} \mathrm{C}$, are higher than those of the northern body granite $\left(570.69-629.98^{\circ} \mathrm{C}\right)$ (Table S2).

Intrusion depth of granites in the studied area can be estimated based on the calculated crystallization pressures $(\mathrm{P})$ using the equation: $\mathrm{P}=\rho \mathrm{gh}$, where $\mathrm{P}$ is crystallization pressures (GPa), $\rho$ is the density of the continental crust $\left(2.73 \mathrm{~kg} / \mathrm{m}^{3}\right), \mathrm{g}$ is the specific gravity (about $10.0 \mathrm{~m} / \mathrm{s}^{2}$ ), and $\mathrm{h}$ is the depth $(\mathrm{km})$. The intrusion depth of the southern body granite $(12-14 \mathrm{~km})$ is slightly higher than the northern body granite's (12-13 km) (Table S2). The Ps and Ts are reasonable, as confirmed by comparative calculation with [30], and the intrusion depths are related to crustal level according to the study reported by [31]. The obtained crystallization P-T conditions and intrusion depths are the first report for the CBG in Thailand.

\section{Petrogenesis}

According to the field investigation, the granitic rocks can be characterized by porphyritic texture (Fig. 1a,c) together with the main compositions of quartz, K-felspar, plagioclase, biotite, and muscovite. These petrographic characters are comparable to the typical characters of the megacrystic biotite granites in the CBG $[4,5]$. Moreover, the appearance of ilmenite as opaque minerals in these granites indicates that these granites can be classified as ilmenite series [1], which is also consistent with the classified granites in the CBG [6].

Based on the whole-rock geochemistry, the silica $\left(\mathrm{SiO}_{2}\right)$ and total alkaline $\left(\mathrm{Na}_{2} \mathrm{O}+\mathrm{K}_{2} \mathrm{O}\right)$, plotted in mostly the granite field with some granodiorite composition, are comparable to the $\mathrm{CBG}$ field (yellow field) reported by [4] and the granites in the Inthanon zone (blue shade) (Fig. 2b).
The plot of $\mathrm{SiO}_{2}$ versus $\mathrm{K}_{2} \mathrm{O}$ indicates that these rocks were originated from high-K calc-alkaline to shoshonitic magma the same as the data reported by [4] (Fig. 2c). In addition, these rocks can be constrained to high-K calc-alkaline magma by comparing to the composition of granites in the Inthanon zone of CBG reported by [16]. The plots of $\mathrm{Al} /(\mathrm{Ca}+\mathrm{Na}+\mathrm{K})$ against $\mathrm{Al} /(\mathrm{Na}+\mathrm{K})$ of [22] (Fig. 2d) indicate that these granitic rocks are peraluminous S-type granite compositions that are comparable to the CBG reported by $[4,16]$.

With respect to the Harker variation diagrams (Fig. 3), most of them show scattered distribution, probably indicating the S-type granite feature comparable to the CBG $[4,16]$. Some correlations in the Harker variation diagrams of granite, aplite, and pegmatite should indicate the close magmatism relationship. Although some variation plots of $\mathrm{Na}_{2} \mathrm{O}$ show positive correlation with $\mathrm{SiO}_{2}$ that might have been affected by the crystallization of feldspar in these granites, varying from oligoclase, albite, and orthoclase, these variation plots are still comparable to the CBG fields reported by $[4,16]$.

The depletions of $\mathrm{Ba}, \mathrm{Nb}$, and $\mathrm{Ti}$; and the enrichments of $\mathrm{Rb}, \mathrm{Th}, \mathrm{K}$, and $\mathrm{Pb}$ in the primitive mantle-normalized spider diagram (Fig. 4a) are comparable to the collisional granite [25]. Moreover, both the primitive mantle-normalized spider diagram and the chondrite-normalized REE patterns of the granites are comparable to the CBG in the Inthanon zone [16]. The negative anomaly of $\mathrm{Eu}$ in the chondrite-normalized REE patterns (Fig. 4b) was probably affected by the fractionation of plagioclase [25]. Although the REE patterns of the aplite are different from the granites that might be affected by the tetrad effect [32], the wide range of chondrite-normalized La/Yb ratios (1.87-10.49) and $\mathrm{Zr} / \mathrm{Hf}$ ratios (12-30) can indicate fractionation related to the evolution of silica melt [33]. The decreasing $\mathrm{Zr} / \mathrm{Hf}$ ratios from granites (30-33) to aplite (10) is related to the increasing evolution of high-silica melt [32] which is consistent with the $\mathrm{SiO}_{2}$ contents of these rocks.

In terms of the magmatic sources, the plots of mineral chemistry of biotite of [34] can clearly indicate that the magmatic sources of these rocks are crust sources (Fig. 5a). These plotted crustal magmatic sources are confirmed by the calculated intrusion depths. Furthermore, the primitive mantlenormalized spider diagram is comparable to the upper crust [26] which is also consistent with the CBG in the Inthanon zone (represented by the blue shaded area in Fig. $4 \mathrm{ab}$ ) that originated from the 

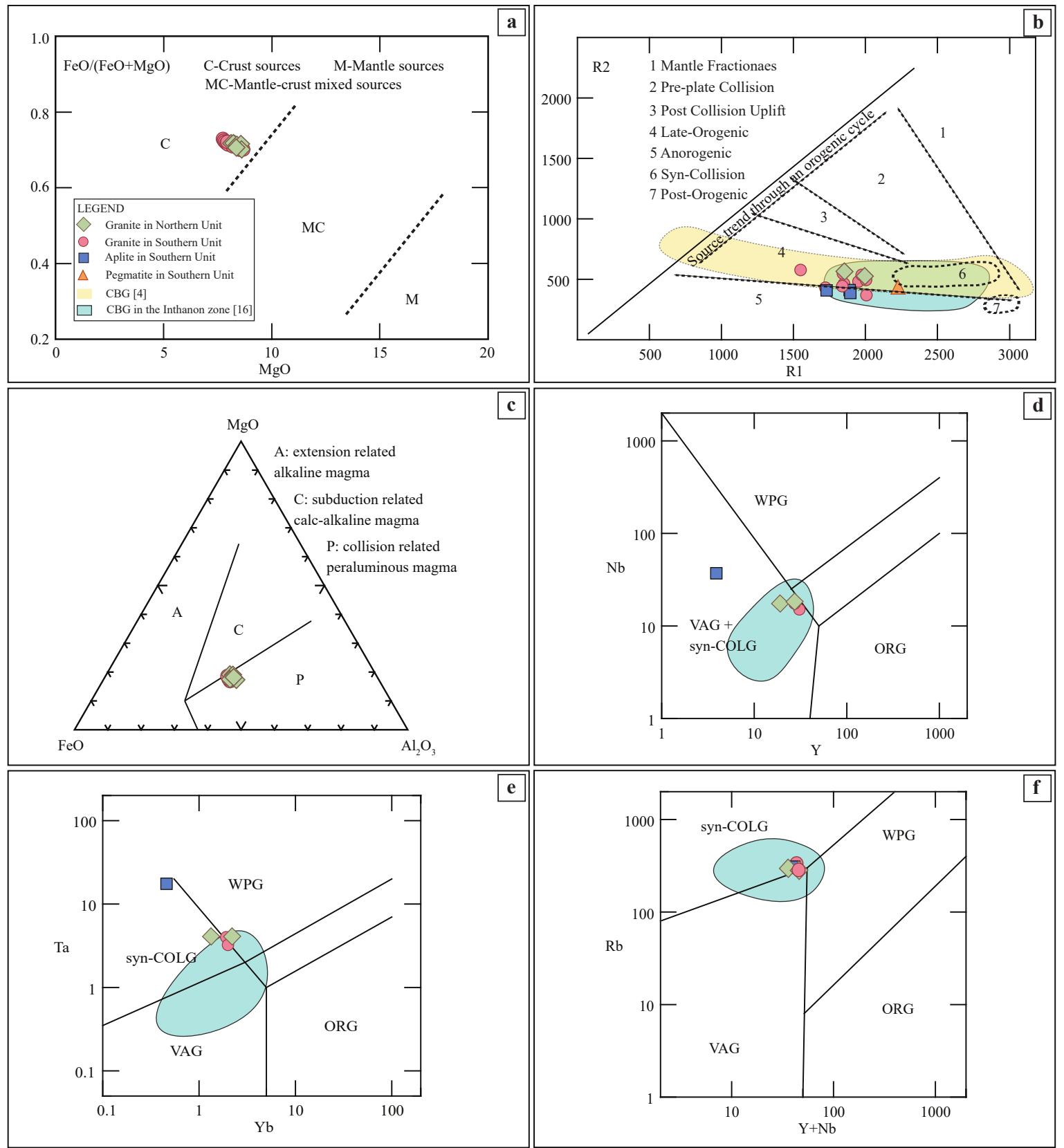

Fig. 5 Plots of: (a) $\mathrm{MgO}$ against $\mathrm{FeO} /(\mathrm{FeO}+\mathrm{MgO}$ ) diagram [34] of biotite in granites from the study area; (b) R1 against R2 geotectonic discrimination diagram [36] (R1, $4 \mathrm{Si}-11(\mathrm{Na}+\mathrm{K})-2(\mathrm{Fe}+\mathrm{Ti})$; $\mathrm{R} 2,6 \mathrm{Ca}+2 \mathrm{Mg}+\mathrm{Al})$; (c) ternary plots of $\mathrm{FeO}-\mathrm{MgO}-\mathrm{Al}_{2} \mathrm{O}_{3}$ of biotite [35]; trace-element based geotectonic classification of granitoids by [37]: (d) $\mathrm{Y}$ against $\mathrm{Nb}$, (e) $\mathrm{Yb}$ against $\mathrm{Ta}$, and (f) $\mathrm{Y}+\mathrm{Nb}$ against $\mathrm{Rb}$.

crustal components [16].

\section{Tectonic implication}

The combination of the mineral chemistry, wholerock geochemistry, and comparison to the previous studies of the CBG can be used to imply the tectonic setting for the granitic formation in the Dan Chang area. Ternary plots of $\mathrm{FeO}-\mathrm{MgO}-\mathrm{Al}_{2} \mathrm{O}_{3}$ of biotite compositions [35] suggest that the peraluminous magmas are related to the collision (Fig. 5c). Moreover, the plots of R1 $(4 \mathrm{Si}-11(\mathrm{Na}+\mathrm{K})-2(\mathrm{Fe}+\mathrm{Ti}))$ and $\mathrm{R} 2(6 \mathrm{Ca}+2 \mathrm{Mg}+\mathrm{Al})$ geotectonic discrimination diagram [36], which uses the functions of major compositions of the granitic rocks, indicate that 
these rocks relate to syn-collisional to late-orogenic (Fig. 5b). From the study of immobile elements, the plot of $\mathrm{Nb}$ against $\mathrm{Y}$ [37] indicates that all granitic rocks are related to the volcanic arc granites and the syn-collisional granites (Fig. 5d). Ta versus $\mathrm{Yb}$ diagram [37] suggests that these rocks are close to the syn-collisional granites and the within-plate granite (Fig. 5e). The plot of $\mathrm{Rb}$ against $\mathrm{Y}+\mathrm{Nb}$ [37] indicates that these rocks are more likely related to the syn-collisional granites than the volcanic arc granite or the within-plate granites (Fig. 5f). Moreover, the primitive mantle-normalized spider diagram (Fig. 4a) and the chondrite-normalized REE patterns (Fig. 4b) are clearly comparable to those of the syn-collisional granites from the western segment of the Jiangnan Orogen, South China [25]. Based on the tectonic discrimination diagrams (Fig. 5b-f), the granitic rocks of Dan Chang area are comparable to the CBG [4], especially the granites in the Inthanon zone, Northern Thailand (Fig. S1a), which originated from syn-collisional crustal thickening and subsequent post-collision after the closure of the Paleotethyan during Late-Triassic ( 200-230 Ma) $[16,38-40]$.

\section{CONCLUSION}

Granitic rocks in Dan Chang area, including the northern and southern units, are composed of granite, aplite, and pegmatite. The granitic rocks are characterized by porphyritic texture with the assemblages of quartz, K-feldspar, plagioclase, biotite, muscovite, and some accessory minerals of zircon, apatite, and ilmenite. The crystallization P-T conditions of the northern body and the southern body granites are $3.36-3.67 \mathrm{kbar}, 570.69-629.98^{\circ} \mathrm{C}$ and $3.32-3.76 \mathrm{kbar}, 623.98-655.43^{\circ} \mathrm{C}$, respectively. The calculated intrusion depth of the southern granite is $12-14 \mathrm{~km}$, while $12-13 \mathrm{~km}$ is the depth of the northern granites. Moreover, these granitic rocks are classified into peraluminous S-type granite formed by high-K-calc-alkaline magma from upper crustal sources comparable to the CBG of Thailand. Finally, these granitic rocks are related to syn-collision to late orogeny which can be compared $\mathrm{w}$ the syncollisional crustal thickening and subsequent postcollisional after the closure of paleotethyan during Late-Triassic.

\section{Appendix A. Supplementary data}

Supplementary data associated with this article can be found at http://dx.doi.org/10.2306/ scienceasia1513-1874.2021.066.
Acknowledgements: The authors would like to express their special gratitude to the Department of Geology, Faculty of Science, Chulalongkorn University for research facilities and analytical techniques. The authors are also very grateful to Mr. Ratchapon Nhootong for the field investigation and the laboratory supports.

\section{REFERENCES}

1. Ishihara S, Sawata H, Shibata K, Terashina S, Arrykul S, Sata K (1980) Granites and Sn-W deposits of Penisular Thailand. Mining Geol 30, 223-241.

2. Pongsapich W, Pisutha-Arnond V, Charusiri P (1983) Reviews of felsic plutonic rocks in Thailand. Proceedings of the Workshop on Stratigraphic Correlation of Thailand and Malaysia, pp 213-232.

3. Charusiri P, Clark AH, Farrar E (1989) Miocene (-oligocene) events in Thailand: Evidence from ${ }^{40} \mathrm{Ar} /{ }^{39} \mathrm{Ar}$ and K-Ar geochronology. Annual Technical Meeting 1989: Geology and Mineral Resources of Thailand, Indochina and Burma, Chiang Mai, Thailand.

4. Nakapadungrat S, Putthapiban P (1992) Granites and associated mineralization in Thailand. In: Piancharoen C, et al (Eds) Proceedings of National Conference on Geologic Resources of Thailand: Potential for Future Development, Department of Mineral Resources, Bangkok, Thailand, pp 153-171.

5. Putthapiban P (2002) Geology and geochronology of the igneous rocks of Thailand. In: The Symposium on Geology of Thailand, Bangkok, Thailand, pp 261-283.

6. Charusiri P, Clark AH, Farrar E, Archibald, D, Charusiri B (1993) Granite belts in Thailand: evidence from the 40Ar/39Ar geochronological and geological syntheses. J Southeast Asian Earth Sci 8, 127-136.

7. Salam A, Zaw K, Meffre S, McPhie J, Lai CK (2014) Geochemistry and geochronology of epithermal Auhosted Chatree volcanic setting sequence: Implication for tectonic setting of Loei Fold Belt in central Thailand. Gondwa Res 26, 198-217.

8. Fanka A, Tsunogae T, Daorerk V, Tsutsumi Y, Takamura Y, Endo T, Sutthirat C (2016) Petrogeochemistry and mineral chemistry of Late Permain hornblendite and hornblende gabbro from the Wang Nam Khiao area, Nakhon Ratchasima, Thailand: Indication of Palaeo-Tethyan subduction. $J$ Asian Earth Sci 130, 239-255.

9. Fanka A, Tsunogae T, Daorerk V, Tsutsumi Y, Takamura Y, Endo T, Sutthirat C (2018) Petrochemistry and zircon U-Pb geochronology of granitic rocks in the Wang Nam Khiao area, Nakhon Ratchasima, Thailand: Implications for petrogenesis and tectonic setting. $J$ Asian Earth Sci 157, 92-118.

10. Nantasin P, Hauzenberger C, Liu X, Krenn K, Dong Y, Thöni M, Wathanakul P (2012) Occurrence of the high grade Thabsila metamorphic complex within 
the low grade Three Pagodas shear zone, Kanchanaburi Province, western Thailand: Petrology and geochronology. J Asian Earth Sci 60, 68-87.

11. Cobbing EJ, Pitfield PEJ, Derbyshire DPF, Mallick DIJ (1992) The Granites of the South-East Asian Tin Belt, Overseas Mem Br Geol Surv 10, HMSO, London.

12. Chappell BW, White AJR (1974) Two contrasting granite types. Pacific Geo 8, 173-174.

13. Ishihara S (1977) The magnetite-series and Ilmeniteseries granite rocks. Mining Geol 27, 293-305.

14. Department of Mineral Resources (2006) Geological Map of Thailand 1:50000, Amphoe Dan Chang, Department of Mineral Resources, Thailand.

15. Sone M, Metcalfe I (2008) Parallel Tethyan sutures in mainland Southeast Asia: new insights for PaleoTethys closure and implications for the Indosinian orogeny. C R Geosci 340, 166-179.

16. Wang Y, He H, Cawood PA, Srithai B, Feng Q, Fan W, Yuzhi Z, Qian X (2016) Geochronology, elemental and Sr-Nd-Hf-O isotopic constraints on the petrogenesis of the Triassic post-collisional granitic rocks in NW Thailand and its Paleotethyan implications. Lithos 266, 264-286.

17. Qian X, Feng Q, Wang Y, Zhao T, Zi JW, Udchachon M, Wang Y (2017) Late Triassic post-collisional granites related to Paleotethyan evolution in SE Thailand: Geochronological and geochemical constraints. Lithos 286, 440-453.

18. Shapiro L (1975) Rapid Analysis of Silicate, Carbonate and Phosphate Rocks, revised edn, Geological Survey Bulletin 1401, United State Government Printing Office, Washington, USA.

19. Cox KG, Bell BG, Pankhurst RJ (1979) The Interpretation of Igneous Rocks, Unwin Hyman, London.

20. Peccerillo A, Taylor SR (1976) Geochemistry of Eocene calc-alkaline volcanic rocks from the Kastamonu area, Northern Turkey. Contrib Mineral Petrol 58, 63-81.

21. Rickwood PC (1989) Boundary line within petrolkogic diagrams which use oxides of major and minor elements. Lithos 22, 247-263.

22. Shand SJ (1943) Eruptive Rocks, Their Genesis, Composition, Classification, and Their Relation to OreDeposits with a Chapter on Meteorite, John Wiley \& Sons, New York, USA.

23. Harker A (1909) The Natural History of Igneous Rocks, Methuen, London.

24. Sun SS, McDonough WF (1989) Chemical and isotopic systematics of Oceanic basalts: implications for mantle composition and process. $J$ Geol Soc London 42, 313-345.

25. Yao J, Shu L, Santosh M, Zhao G (2014) Neoproterozoic arc-related mafic-ultramafic rocks and syn-collision granite from the western segment of the Jiangnan Orogen, South China: Constraints on the Neoproterozoic assembly of the Yangtze and Cathaysia Block. Precambrian Res 243, 39-62.

26. Rudnick RL, Gao S (2003) Composition of the continental crust. In: Rudnick RL (ed) The Crust, Elsevier, Oxford.

27. Deer WA, Howie RA, Zussmann J (1966) An Introduction of Rock-Forming Minerals, Longmans, London.

28. Uchida E, Endo S, Makino M (2007) Relationship between solidification depth of granitic rocks and formation of hydrothermal ore deposits. Resour Geol $57,47-56$.

29. Henry D, Guidotti C, Thomson J (2005) The Ti-saturation surface for low-to-medium pressure Metapelitic biotites: Implications for geothermometry and Ti-substitution mechanism. Amer Miner 90, 31-328.

30. Chi WC, Reed DL (2008) Evolution of shallow, crustal thermal structure from subduction to collision: an example from Taiwan. Geol Soc Am Bull 120, 679-690.

31. Tewari HC, Rajendra Prasad B, Kumar P (2018) Global and Indian scenario of crustal thickness. In: Structure and Tectonics of the Indian Continental Crust and Its Adjoining Region, pp 211-224.

32. Yasnygina TA, Rasskazov SV (2008) Tetrad effect in rare Earth element distribution patterns: Evidence from the Paleozoic Granitoids of the Oka Zone, Eastern Sayan. Geochem Int 46, 814-825.

33. Zaraisky GP, Aksyuk AM, Devyatova VN, Udoratina OV, Chevychelov VY (2009) The Zr/Hf ratio as a fractionation indicator of rare-metal granites. $J$ Petrol 17, 25-45.

34. Zhou ZX (1986) The origin of intrusive mass in Fengshandong, Hubei province. Acta Petrologica Sinica 2, 59-70.

35. Abdel-Rahman AM (1994) Nature of biotites from alkaline, calc-alkaline and peralumnous magmas. $J$ Petrol 35, 525-541.

36. Batchelor RA, Bowden P (1985) Petrogenetic interpretation of granitoid rocks series using multicationic parameters. Chem Geol 48, 43-55.

37. Pearce JA, Harris NBW, Tindle AG (1984) Trace element discrimination diagrams for the tectonic interpretation of granitic rock. $J$ Petrol 25, 956-983.

38. Searle MP, Whitehouse MJ, Robb LJ, Ghani AA, Hutchison CS, Sone M, NG S, et al (2012) Tectonic evolution of the Sibumasu-Indochina terrane collision zone in Thailand and Malaysia: Constrains from new U-Pb zircon chronology of SE Asian tin granitoids. J Geol Soc 169, 489-500.

39. Phajuy B, Singtuen V (2019) Petrochemical characteristics of Tak volcanic rocks, Thailand: Implication for tectonic significance. ScienceAsia 45, 350-360.

40. Wonglak S, Sutthirat C, Assawincharoenkij T (2020) Petrochemistry of Lan Sang metamorphic suites. ScienceAsia 46, 481-489. 


\section{Appendix A. Supplementary data}

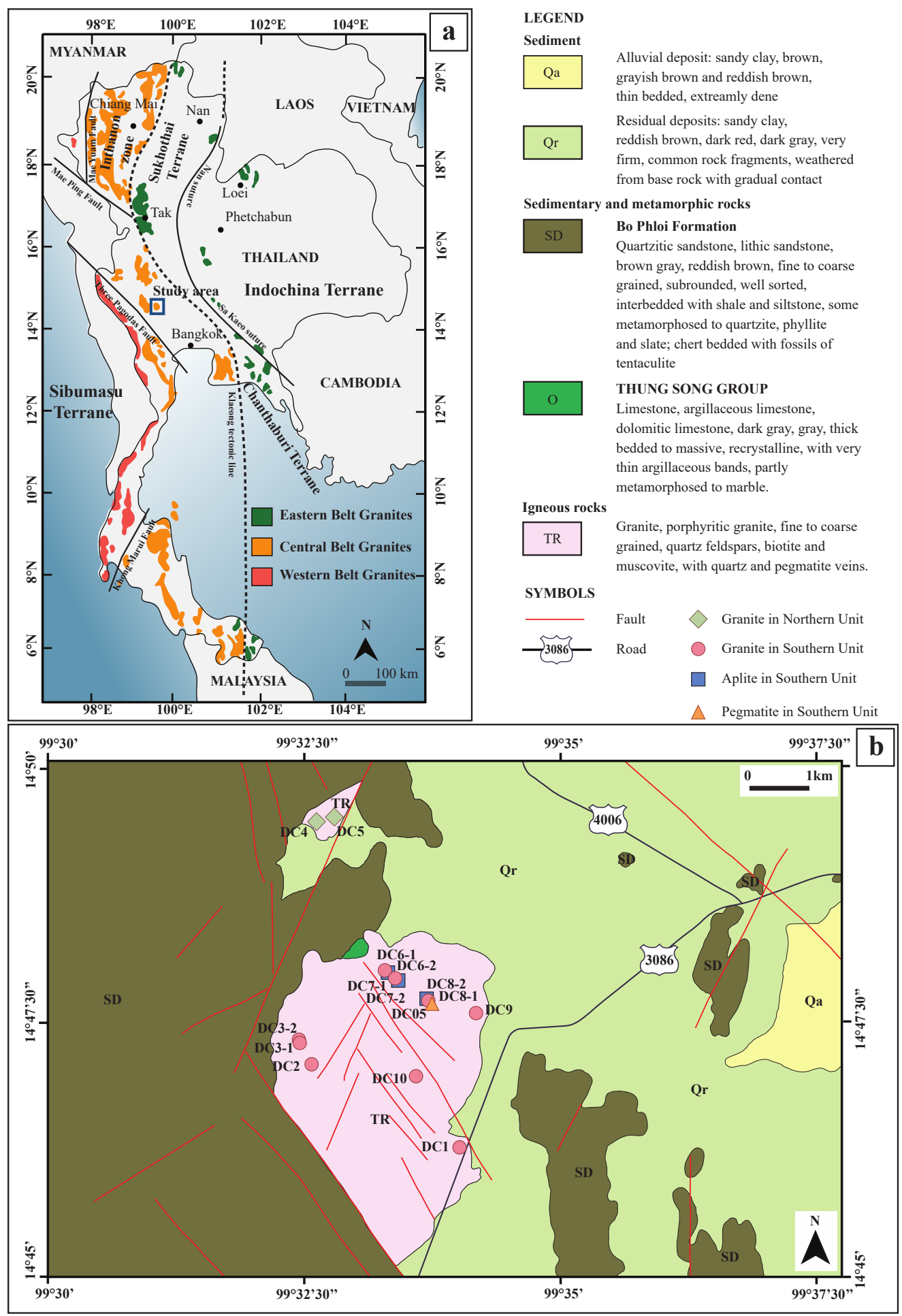

Fig. S1 (a) Index map of Thailand showing the distribution of the three granite belts $[4,6,15-17]$; (b) geological map of the studied area in Dan Chang District, Suphan Buri Province, Thailand [14] showing locations of representative samples. 
Table S1 Whole-rock geochemistry of granites in Dan Chang area, Suphan Buri Province, Central Thailand (major and minor oxide in $\mathrm{wt} \%$, trace elements and REE in $\mathrm{ppm})$.

\begin{tabular}{|c|c|c|c|c|c|c|c|c|c|c|c|c|c|c|c|}
\hline \multirow{3}{*}{$\begin{array}{l}\text { Unit } \\
\text { Rock } \\
\text { Sample }\end{array}$} & \multirow{2}{*}{\multicolumn{2}{|c|}{$\begin{array}{c}\text { Northern } \\
\text { Granite }\end{array}$}} & \multicolumn{13}{|c|}{ Southern } \\
\hline & & & \multicolumn{9}{|c|}{ Granite } & \multicolumn{3}{|c|}{ Aplite } & \multirow{2}{*}{$\frac{\text { Pegmatite }}{\text { DC05 }}$} \\
\hline & DC4 & DC5 & DC1 & DC2 & DC3-1 & DC3-2 & DC6-1 & DC7-1 & DC8-1 & DC9 & DC10 & DC6-2 & DC7-2 & DC8-2 & \\
\hline \multicolumn{16}{|c|}{ Major and minor oxides (wt\%) } \\
\hline $\begin{array}{l}\mathrm{SiO}_{2} \\
\mathrm{TiO}_{2} \\
\mathrm{Al}_{2} \mathrm{O}_{3} \\
\mathrm{FeO}_{\mathrm{t}} \\
\mathrm{MnO} \\
\mathrm{MgO} \\
\mathrm{CaO} \\
\mathrm{Na}_{2} \mathrm{O} \\
\mathrm{K}_{2} \mathrm{O} \\
\mathrm{P}_{2} \mathrm{O}_{5} \\
\mathrm{LOI} \\
\text { Total }\end{array}$ & $\begin{array}{r}68.62 \\
0.32 \\
17.06 \\
2.75 \\
0.03 \\
1.73 \\
0.90 \\
3.66 \\
5.73 \\
0.30 \\
0.97 \\
100.95\end{array}$ & $\begin{array}{r}66.27 \\
0.20 \\
16.44 \\
2.05 \\
0.03 \\
0.82 \\
1.00 \\
3.45 \\
4.88 \\
0.36 \\
0.86 \\
96.34\end{array}$ & $\begin{array}{r}67.85 \\
0.19 \\
16.83 \\
2.01 \\
0.03 \\
0.95 \\
0.98 \\
3.60 \\
4.99 \\
0.33 \\
0.73 \\
98.48\end{array}$ & $\begin{array}{r}69.42 \\
0.21 \\
16.60 \\
2.04 \\
0.02 \\
0.97 \\
0.84 \\
3.98 \\
5.27 \\
0.32 \\
0.83 \\
100.50\end{array}$ & $\begin{array}{r}73.59 \\
0.14 \\
13.68 \\
1.11 \\
0.01 \\
0.64 \\
0.64 \\
4.93 \\
4.46 \\
0.22 \\
0.53 \\
99.94\end{array}$ & $\begin{array}{r}69.81 \\
0.18 \\
15.18 \\
1.93 \\
0.02 \\
0.99 \\
0.78 \\
4.80 \\
4.72 \\
0.27 \\
0.76 \\
99.43\end{array}$ & $\begin{array}{r}65.06 \\
0.41 \\
16.54 \\
2.94 \\
0.03 \\
1.43 \\
1.43 \\
3.13 \\
5.24 \\
0.31 \\
0.70 \\
97.22\end{array}$ & $\begin{array}{r}61.73 \\
0.47 \\
16.93 \\
3.22 \\
0.03 \\
1.57 \\
1.56 \\
3.23 \\
5.38 \\
0.28 \\
0.60 \\
95.00\end{array}$ & $\begin{array}{r}67.20 \\
0.36 \\
16.12 \\
2.77 \\
0.03 \\
1.44 \\
1.39 \\
3.37 \\
4.96 \\
0.30 \\
0.70 \\
98.63\end{array}$ & $\begin{array}{r}66.27 \\
0.33 \\
15.71 \\
2.43 \\
0.02 \\
1.08 \\
1.24 \\
3.31 \\
4.69 \\
0.27 \\
0.60 \\
95.95\end{array}$ & $\begin{array}{r}67.85 \\
0.19 \\
16.83 \\
2.01 \\
0.03 \\
0.95 \\
0.98 \\
3.60 \\
4.99 \\
0.33 \\
0.85 \\
98.00\end{array}$ & $\begin{array}{r}69.91 \\
0.04 \\
16.81 \\
0.81 \\
0.00 \\
0.09 \\
0.71 \\
3.95 \\
5.46 \\
0.38 \\
0.47 \\
98.63\end{array}$ & $\begin{array}{r}70.71 \\
0.03 \\
17.95 \\
0.53 \\
0.01 \\
0.11 \\
0.48 \\
4.69 \\
5.29 \\
0.39 \\
0.70 \\
100.87\end{array}$ & $\begin{array}{r}73.39 \\
0.02 \\
16.67 \\
0.53 \\
0.01 \\
0.09 \\
0.51 \\
5.39 \\
4.26 \\
0.42 \\
0.50 \\
101.81\end{array}$ & $\begin{array}{r}69.08 \\
0.20 \\
16.82 \\
4.13 \\
0.03 \\
0.91 \\
0.48 \\
2.03 \\
6.30 \\
0.48 \\
0.80 \\
97.98\end{array}$ \\
\hline \multicolumn{16}{|c|}{ Trace elements (ppm) } \\
\hline$\overline{\mathrm{Li}}$ & 10 & 10 & 10 & - & - & - & - & - & 70 & - & - & - & - & 10 & - \\
\hline $\mathrm{V}$ & 26 & 16 & 13 & - & - & - & - & - & 25 & - & - & - & - & 5 & - \\
\hline $\mathrm{Cr}$ & 130 & 110 & 110 & - & - & - & - & - & 150 & - & - & - & - & 190 & - \\
\hline Sc & 5 & 5 & 3 & - & - & - & - & - & 5 & - & - & - & - & 3 & - \\
\hline $\mathrm{Ni}$ & 5 & 2 & 4 & - & - & - & - & - & 8 & - & - & - & - & 1 & - \\
\hline $\mathrm{Cu}$ & 2 & 2 & $<1$ & - & - & - & - & - & 2 & - & - & - & - & 1 & - \\
\hline As & 6 & 12 & $<5$ & - & - & - & - & - & 7 & - & - & - & - & $<5$ & - \\
\hline Co & 2 & 1 & 2 & - & - & - & - & - & 3 & - & - & - & - & $<1$ & - \\
\hline $\mathrm{Zn}$ & $2 \overline{1}$ & 29 & $3 \overline{3}$ & - & - & - & - & - & 39 & - & - & - & - & 12 & - \\
\hline $\mathrm{Ga}$ & 17.8 & 19.2 & 17.9 & - & - & - & - & - & 19.1 & - & - & - & - & 24.3 & - \\
\hline $\mathrm{Rb}$ & 282 & 297 & 281 & - & - & - & - & - & 318 & - & - & - & - & 308 & - \\
\hline $\mathrm{Sr}$ & 114.5 & 71.9 & 67.1 & - & - & - & - & - & 86.9 & - & - & - & - & 7.8 & - \\
\hline $\mathrm{Y}$ & 27.6 & 18.6 & 30.2 & - & - & - & - & - & 26.7 & - & - & - & - & 3.9 & - \\
\hline $\mathrm{Zr}$ & 202 & 102 & 88 & - & - & - & - & - & 163 & - & - & - & - & 20 & - \\
\hline Sn & 21 & 26 & 22 & - & - & - & - & - & 19 & - & - & - & - & 30 & - \\
\hline $\mathrm{Cs}$ & 2.96 & 9.8 & 8.55 & - & - & - & - & - & 19.65 & - & - & - & - & 5.62 & - \\
\hline $\mathrm{Ba}$ & 1025 & 447 & 474 & - & - & - & - & - & 551 & - & - & - & - & 13.1 & - \\
\hline $\mathrm{La}$ & 47.8 & 21.7 & 22.9 & - & - & - & - & - & 35.7 & - & - & - & - & 1.2 & - \\
\hline $\mathrm{Ce}$ & 97.3 & 46.1 & 47.1 & - & - & - & - & - & 75 & - & - & - & - & 2.7 & - \\
\hline $\operatorname{Pr}$ & 10.95 & 5.27 & 5.23 & - & - & - & - & - & 8.53 & - & - & - & - & 0.31 & - \\
\hline $\mathrm{Nd}$ & 39.1 & 19.2 & 19.6 & - & - & - & - & - & 31.4 & - & - & - & - & 1.3 & - \\
\hline $\mathrm{Sm}$ & 7.76 & 4.62 & 4.72 & - & - & - & - & - & 6.89 & - & - & - & - & 0.55 & - \\
\hline $\mathrm{Gd}$ & 5.98 & 3.91 & 4.65 & - & - & - & - & - & 5.46 & - & - & - & - & 0.54 & - \\
\hline $\mathrm{Tb}$ & 0.94 & 0.63 & 0.75 & - & - & - & - & - & 0.86 & - & - & - & - & 0.11 & - \\
\hline Dy & 2.27 & 3.5 & 4.71 & - & - & - & - & - & 4.91 & - & - & - & - & 0.72 & - \\
\hline Ho & 0.92 & 0.62 & 0.84 & - & - & - & - & - & 0.88 & - & - & - & - & 0.1 & - \\
\hline $\mathrm{Er}$ & 2.69 & 1.63 & 2.32 & - & - & - & - & - & 2.48 & - & - & - & - & 0.33 & - \\
\hline $\mathrm{Tm}$ & 0.42 & 0.27 & 0.38 & - & - & - & - & - & 0.39 & - & - & - & - & 0.06 & - \\
\hline $\mathrm{Yb}$ & 2.67 & 1.63 & 2.28 & - & - & - & - & - & 2.44 & - & - & - & - & 0.46 & - \\
\hline $\mathrm{Lu}$ & 0.38 & 0.23 & 0.33 & - & - & - & - & - & 0.37 & - & - & - & - & 0.05 & - \\
\hline $\mathrm{Nb}$ & 18.3 & 17.5 & 15.2 & - & - & - & - & - & 16.6 & - & - & - & - & 37.1 & - \\
\hline $\mathrm{Ta}$ & 3.2 & 3.2 & 3 & - & - & - & - & - & 2.6 & - & - & - & - & 17.5 & - \\
\hline $\mathrm{Pb}$ & 33 & 41 & 49 & - & - & - & - & - & 46 & - & - & - & - & 18 & - \\
\hline Th & 41.5 & 17.85 & 16.75 & - & - & - & - & - & 28.8 & - & - & - & - & 1.04 & - \\
\hline $\mathrm{U}$ & 7.7 & 5.48 & 6.86 & - & - & - & - & - & 11.95 & - & - & - & - & 18.55 & - \\
\hline Mo & $<1$ & $<1$ & $<1$ & - & - & - & - & - & 1 & - & - & - & - & $<1$ & - \\
\hline Eu & 0.9 & 0.55 & 0.62 & - & - & - & - & - & 0.72 & - & - & - & - & 0.03 & - \\
\hline Hf & 6.7 & 3.4 & 2.9 & - & - & - & - & - & 5 & - & - & - & - & 1.7 & - \\
\hline
\end{tabular}


Table S2 Representative EPMA analyses of biotite in granites from Dan Chang area, Suphan Buri Province, Central Thailand.

\begin{tabular}{|c|c|c|c|c|c|c|c|c|c|c|c|c|}
\hline \multirow{2}{*}{$\begin{array}{l}\text { Unit } \\
\text { Analysis no. }\end{array}$} & \multicolumn{6}{|c|}{ Northern unit } & \multicolumn{6}{|c|}{ Southern unit } \\
\hline & 4bt2-1 & $4 \mathrm{bt} 2-2$ & $4 b t 3-1$ & $4 b t 3-2$ & 4bt4-1 & $4 b t 4-2$ & $11 \mathrm{bt} 2-1$ & $11 \mathrm{bt} 2-2$ & 11 inbt2-1 & 11 inbt2-2 & $11 z b t 3-1$ & $11 \mathrm{zbt} 3-2$ \\
\hline$\overline{\mathrm{SiO}_{2}}$ & 38.95 & 38.85 & 38.40 & 38.91 & 38.79 & 38.80 & 38.38 & 38.86 & 38.26 & 38.46 & 38.25 & 38.57 \\
\hline $\mathrm{Al}_{2} \mathrm{O}_{3}$ & 17.61 & 17.42 & 17.44 & 17.44 & 17.23 & 17.09 & 17.71 & 17.45 & 17.47 & 17.48 & 17.10 & 17.07 \\
\hline $\mathrm{TiO}_{2}{ }^{3}$ & 2.39 & 2.42 & 1.87 & 1.95 & 1.85 & 1.80 & 2.86 & 2.65 & 2.52 & 2.67 & 2.34 & 2.35 \\
\hline $\mathrm{FeO}_{\mathrm{t}}^{2}$ & 20.24 & 20.08 & 20.52 & 20.83 & 20.71 & 20.94 & 20.72 & 20.22 & 20.96 & 20.96 & 20.48 & 20.86 \\
\hline $\mathrm{MnO}$ & 0.29 & 0.30 & 0.32 & 0.30 & 0.34 & 0.30 & 0.28 & 0.25 & 0.28 & 0.26 & 0.29 & 0.33 \\
\hline $\mathrm{MgO}$ & 8.22 & 8.41 & 8.65 & 8.09 & 8.63 & 8.42 & 7.80 & 8.00 & 8.37 & 8.22 & 8.66 & 8.60 \\
\hline $\mathrm{CaO}$ & 0.05 & 0.03 & 0.04 & 0.16 & 0.00 & 0.00 & 0.00 & 0.00 & 0.00 & 0.00 & 0.00 & 0.02 \\
\hline $\mathrm{Na}_{2} \mathrm{O}$ & 0.08 & 0.07 & 0.07 & 0.01 & 0.05 & 0.05 & 0.10 & 0.05 & 0.03 & 0.06 & 0.06 & 0.06 \\
\hline $\mathrm{K}_{2} \mathrm{O}$ & 8.09 & 8.82 & 8.80 & 8.49 & 8.42 & 8.17 & 8.75 & 8.84 & 8.13 & 8.21 & 8.40 & 8.34 \\
\hline Total & 96.12 & 96.77 & 96.91 & 96.32 & 96.03 & 96.44 & 96.60 & 96.39 & 96.16 & 96.69 & 96.26 & 96.91 \\
\hline \multicolumn{13}{|l|}{$10(\mathrm{O})$} \\
\hline $\mathrm{Si}$ & 637 & 2.623 & 2.592 & 2.647 & 2.644 & 2.624 & 2.607 & 2.638 & 2.607 & 2.601 & 2.600 & 2.602 \\
\hline $\mathrm{Al}$ & 1.405 & 1.386 & 1.387 & 1.398 & 1.384 & 1.362 & 1.418 & 1.395 & 1.403 & 1.393 & 1.370 & 1.357 \\
\hline $\mathrm{Ti}$ & 0.122 & 0.123 & 0.095 & 0.100 & 0.095 & 0.091 & 0.146 & 0.135 & 0.129 & 0.136 & 0.119 & 0.119 \\
\hline $\mathrm{Fe}$ & 1.146 & 1.133 & 1.158 & 1.184 & 1.180 & 1.184 & 1.177 & 1.147 & 1.194 & 1.185 & 1.164 & 1.177 \\
\hline Mn & 0.017 & 0.017 & 0.018 & 0.017 & 0.020 & 0.017 & 0.016 & 0.015 & 0.016 & 0.015 & 0.017 & 0.019 \\
\hline $\mathrm{Mg}$ & 0.829 & 0.846 & 0.869 & 0.820 & 0.876 & 0.848 & 0.790 & 0.809 & 0.850 & 0.827 & 0.876 & 0.865 \\
\hline $\mathrm{Ca}$ & 0.003 & 0.002 & 0.003 & 0.012 & 0.000 & 0.000 & 0.000 & 0.000 & 0.000 & 0.000 & 0.000 & 0.001 \\
\hline $\mathrm{Na}$ & 0.010 & 0.010 & 0.009 & 0.002 & 0.007 & 0.007 & 0.013 & 0.007 & 0.004 & 0.008 & 0.008 & 0.008 \\
\hline $\mathrm{K}$ & 0.699 & 0.759 & 0.758 & 0.736 & 0.732 & 0.705 & 0.758 & 0.765 & 0.706 & 0.708 & 0.728 & 0.717 \\
\hline Total & 6.879 & 6.919 & 6.935 & 6.920 & 6.938 & 6.888 & 6.924 & 6.913 & 6.914 & 6.894 & 6.917 & 6.906 \\
\hline $\mathrm{Mg} /(\mathrm{Fe}+\mathrm{Mg})$ & 0.420 & 0.427 & 0.429 & 0.409 & 0.426 & 0.417 & 0.402 & 0.414 & 0.416 & 0.411 & 0.430 & 0.424 \\
\hline $\mathrm{P}$ (kbar) & 3.67 & 3.53 & 3.54 & 3.62 & 3.52 & 3.36 & 3.76 & 3.6 & 3.65 & 3.58 & 3.41 & 3.32 \\
\hline Temp $\left({ }^{\circ} \mathrm{C}\right)$ & 627.03 & 629.98 & 581.1 & 587.49 & 580.21 & 570.69 & 655.43 & 644.73 & 636.62 & 644.84 & 625.47 & 623.98 \\
\hline Depth $(\mathrm{km})$ & 13 & 13 & 13 & 13 & 13 & 12 & 14 & 13 & 13 & 13 & 13 & 12 \\
\hline
\end{tabular}

Table S3 Representative EPMA analyses of plagioclase in granites from Dan Chang area, Suphan Buri Province, Central Thailand.

\begin{tabular}{|c|c|c|c|c|c|c|c|c|c|c|}
\hline \multirow{2}{*}{$\frac{\text { Unit }}{\text { Analysis no. }}$} & \multicolumn{3}{|c|}{ Northern unit } & \multirow[b]{2}{*}{$4 p 12-3$} & \multicolumn{6}{|c|}{ Southern unit } \\
\hline & 4mp3-1 & $4 p 12-1$ & $4 p 12-2$ & & 11pl1-1 & 11pl11-2 & 11pl13-1 & 11pl3-2 & $9 \mathrm{kp} 1-2$ & $9 \mathrm{kp} 2-1$ \\
\hline $\mathrm{SiO}_{2}$ & 66.57 & 67.33 & 67.84 & 66.97 & 67.37 & 67.46 & 67.76 & 67.21 & 66.71 & 65.96 \\
\hline $\mathrm{Al}_{2} \mathrm{O}_{3}$ & 20.66 & 19.77 & 19.94 & 19.30 & 19.72 & 19.54 & 19.96 & 19.42 & 20.77 & 20.03 \\
\hline $\mathrm{TiO}_{2}{ }^{3}$ & 0.02 & 0.02 & 0.00 & 0.00 & 0.01 & 0.00 & 0.00 & 0.03 & 0.00 & 0.01 \\
\hline $\mathrm{FeO}_{\mathrm{t}}^{2}$ & 0.07 & 0.05 & 0.00 & 0.04 & 0.13 & 0.08 & 0.00 & 0.03 & 0.01 & 0.02 \\
\hline $\mathrm{MnO}$ & 0.03 & 0.00 & 0.00 & 0.00 & 0.03 & 0.00 & 0.01 & 0.02 & 0.01 & 0.03 \\
\hline $\mathrm{MgO}$ & 0.01 & 0.00 & 0.01 & 0.00 & 0.00 & 0.00 & 0.00 & 0.00 & 0.00 & 0.01 \\
\hline $\mathrm{CaO}$ & 1.68 & 0.10 & 0.09 & 0.13 & 2.58 & 2.22 & 2.19 & 2.77 & 0.12 & 0.00 \\
\hline $\mathrm{Na}_{2} \mathrm{O}$ & 10.87 & 11.30 & 11.96 & 13.00 & 10.37 & 10.28 & 10.94 & 10.44 & 11.99 & 12.33 \\
\hline $\mathrm{K}_{2} \mathrm{O}$ & 0.28 & 0.45 & 0.06 & 0.18 & 0.11 & 0.07 & 0.05 & 0.15 & 0.04 & 0.00 \\
\hline Total & 100.24 & 99.65 & 100.45 & 99.62 & 100.82 & 99.98 & 101.09 & 100.16 & 100.01 & 98.74 \\
\hline \multicolumn{11}{|l|}{$8(\mathrm{O})$} \\
\hline $\mathrm{Si}$ & 2.921 & 2.956 & 2.953 & 2.961 & 2.934 & 2.955 & 2.944 & 2.953 & 2.921 & 2.931 \\
\hline $\mathrm{Al}$ & 1.068 & 1.023 & 1.022 & 1.006 & 1.012 & 1.009 & 1.022 & 1.005 & 1.072 & 1.049 \\
\hline $\mathrm{Ti}$ & 0.001 & 0.000 & 0.000 & 0.000 & 0.000 & 0.000 & 0.000 & 0.001 & 0.000 & 0.000 \\
\hline $\mathrm{Fe}$ & 0.003 & 0.002 & 0.000 & 0.002 & 0.005 & 0.003 & 0.000 & 0.001 & 0.000 & 0.001 \\
\hline Mn & 0.001 & 0.000 & 0.000 & 0.000 & 0.001 & 0.000 & 0.000 & 0.001 & 0.000 & 0.001 \\
\hline $\mathrm{Mg}$ & 0.001 & 0.000 & 0.001 & 0.000 & 0.000 & 0.000 & 0.000 & 0.000 & 0.000 & 0.001 \\
\hline $\mathrm{Ca}$ & 0.079 & 0.005 & 0.004 & 0.006 & 0.120 & 0.104 & 0.102 & 0.130 & 0.006 & 0.000 \\
\hline $\mathrm{Na}$ & 0.924 & 0.961 & 1.009 & 1.114 & 0.875 & 0.873 & 0.921 & 0.889 & 1.018 & 1.062 \\
\hline $\mathrm{K}$ & 0.016 & 0.025 & 0.003 & 0.010 & 0.006 & 0.004 & 0.002 & 0.009 & 0.002 & 0.000 \\
\hline Total & 5.014 & 4.994 & 5.012 & 5.098 & 4.972 & 4.960 & 4.997 & 4.991 & 5.032 & 5.057 \\
\hline An & 0.080 & 0.000 & 0.000 & 0.010 & 0.120 & 0.110 & 0.100 & 0.130 & 0.010 & 0.000 \\
\hline $\mathrm{Ab}$ & 0.910 & 0.970 & 0.990 & 0.990 & 0.870 & 0.890 & 0.900 & 0.860 & 0.990 & 1.000 \\
\hline Or & 0.020 & 0.030 & 0.000 & 0.010 & 0.010 & 0.000 & 0.000 & 0.010 & 0.000 & 0.000 \\
\hline
\end{tabular}


Table S4 Representative EPMA analyses of K-feldspar in granites from Dan Chang area, Suphan Buri Province, Central Thailand.

\begin{tabular}{|c|c|c|c|c|c|c|c|c|c|c|}
\hline \multirow{3}{*}{$\begin{array}{l}\text { Unit } \\
\text { Rock } \\
\text { Analysis no. }\end{array}$} & \multicolumn{4}{|c|}{ Northern unit } & \multicolumn{6}{|c|}{ Southern unit } \\
\hline & \multicolumn{4}{|c|}{ Granite } & \multicolumn{4}{|c|}{ Granite } & \multicolumn{2}{|c|}{ Aplite } \\
\hline & 4kf1-2 & 4kf3-1 & 4kf3-2 & $4 \mathrm{kf} 4-2$ & 11kf1-1 & 11pk2-1 & 11pk2-2 & 11ok1-2 & 9kf3-1 & $9 \mathrm{kf} 3-2$ \\
\hline $\mathrm{SiO}_{2}$ & 66.47 & 65.96 & 66.67 & 66.80 & 66.52 & 65.25 & 65.38 & 66.28 & 66.91 & 66.39 \\
\hline $\mathrm{Al}_{2} \mathrm{O}_{3}$ & 20.73 & 21.12 & 20.68 & 20.88 & 20.66 & 20.53 & 20.32 & 20.17 & 20.61 & 20.46 \\
\hline $\mathrm{TiO}_{2}{ }^{3}$ & 0.02 & 0.01 & 0.03 & 0.01 & 0.00 & 0.00 & 0.00 & 0.03 & 0.02 & 0.02 \\
\hline $\mathrm{FeO}_{\mathrm{t}}^{2}$ & 0.02 & 0.05 & 0.04 & 0.00 & 0.05 & 0.00 & 0.04 & 0.11 & 0.00 & 0.00 \\
\hline $\mathrm{MnO}$ & 0.02 & 0.00 & 0.01 & 0.00 & 0.00 & 0.02 & 0.00 & 0.00 & 0.00 & 0.00 \\
\hline $\mathrm{MgO}$ & 0.00 & 0.00 & 0.00 & 0.00 & 0.00 & 0.01 & 0.00 & 0.00 & 0.00 & 0.00 \\
\hline $\mathrm{CaO}$ & 0.00 & 0.00 & 0.22 & 0.00 & 0.01 & 0.00 & 0.00 & 0.02 & 0.00 & 0.00 \\
\hline $\mathrm{Na}_{2} \mathrm{O}$ & 0.67 & 0.00 & 0.27 & 0.26 & 0.71 & 0.56 & 0.56 & 0.89 & 0.50 & 0.49 \\
\hline $\mathrm{K}_{2} \mathrm{O}$ & 10.60 & 12.01 & 11.23 & 11.52 & 11.52 & 12.30 & 13.35 & 12.48 & 10.54 & 10.54 \\
\hline Total & 98.71 & 99.19 & 99.71 & 99.86 & 99.48 & 99.72 & 99.77 & 100.68 & 98.78 & 98.64 \\
\hline \multicolumn{11}{|l|}{$8(\mathrm{O})$} \\
\hline $\mathrm{Si}$ & 2.997 & 2.981 & 2.983 & 2.991 & 2.995 & 2.943 & 2.972 & 2.968 & 3.009 & 2.988 \\
\hline $\mathrm{Al}$ & 1.101 & 1.125 & 1.090 & 1.101 & 1.096 & 1.091 & 1.088 & 1.064 & 1.092 & 1.085 \\
\hline $\mathrm{Ti}$ & 0.001 & 0.000 & 0.001 & 0.000 & 0.000 & 0.000 & 0.000 & 0.001 & 0.001 & 0.001 \\
\hline $\mathrm{Fe}$ & 0.001 & 0.002 & 0.001 & 0.000 & 0.002 & 0.000 & 0.002 & 0.004 & 0.000 & 0.000 \\
\hline $\mathrm{Mn}$ & 0.001 & 0.000 & 0.000 & 0.000 & 0.000 & 0.001 & 0.000 & 0.000 & 0.000 & 0.000 \\
\hline $\mathrm{Mg}$ & 0.000 & 0.000 & 0.000 & 0.000 & 0.000 & 0.001 & 0.000 & 0.000 & 0.000 & 0.000 \\
\hline $\mathrm{Ca}$ & 0.000 & 0.000 & 0.011 & 0.000 & 0.000 & 0.000 & 0.000 & 0.001 & 0.000 & 0.000 \\
\hline $\mathrm{Na}$ & 0.059 & 0.000 & 0.023 & 0.022 & 0.062 & 0.049 & 0.049 & 0.077 & 0.043 & 0.043 \\
\hline $\mathrm{K}$ & 0.609 & 0.692 & 0.641 & 0.658 & 0.662 & 0.707 & 0.774 & 0.713 & 0.605 & 0.605 \\
\hline Total & 4.775 & 4.802 & 4.772 & 4.784 & 4.818 & 4.831 & 4.889 & 4.854 & 4.757 & 4.750 \\
\hline An & 0.000 & 0.000 & 0.020 & 0.000 & 0.000 & 0.000 & 0.000 & 0.000 & 0.000 & 0.000 \\
\hline $\mathrm{Ab}$ & 0.090 & 0.000 & 0.030 & 0.030 & 0.090 & 0.070 & 0.060 & 0.100 & 0.070 & 0.070 \\
\hline Or & 0.910 & 1.000 & 0.950 & 0.970 & 0.910 & 0.930 & 0.940 & 0.900 & 0.930 & 0.930 \\
\hline
\end{tabular}

Table S5 Representative EPMA analyses of ilmenite in granites from Dan Chang area, Suphan Buri Province, Central Thailand.

\begin{tabular}{lcccc}
\hline Unit & \multicolumn{2}{c}{ Southern unit } & \multicolumn{2}{c}{ Northern unit } \\
\hline Analysis no. & 4opq1-1 & 4opq1-2 & 11 opq3-1 & 11 opq3-2 \\
\hline $\mathrm{SiO}_{2}$ & 0.02 & 0.78 & 0.04 & 0.46 \\
$\mathrm{Al}_{2} \mathrm{O}_{3}$ & 0.00 & 0.36 & 0.00 & 0.12 \\
$\mathrm{TiO}_{2}$ & 50.95 & 50.26 & 51.68 & 50.91 \\
$\mathrm{FeO}_{\mathrm{t}}$ & 42.19 & 42.30 & 42.59 & 42.17 \\
$\mathrm{MnO}$ & 5.13 & 5.17 & 5.02 & 4.93 \\
$\mathrm{MgO}$ & 0.06 & 0.06 & 0.05 & 0.06 \\
$\mathrm{CaO}$ & 0.61 & 0.61 & 0.13 & 0.30 \\
$\mathrm{Na}$ & $\mathrm{O}$ & 0.00 & 0.00 & 0.05 \\
$\mathrm{~K}$ & $\mathrm{O}$ & 0.01 & 0.06 & 0.07 \\
$\mathrm{Total}$ & 0.00 & 99.98 & 99.92 & 99.23 \\
\hline $3(\mathrm{O})$ & 99.38 & & & 0.012 \\
$\mathrm{Si}$ & & 0.001 & 0.004 \\
$\mathrm{Al}$ & 0.000 & 0.020 & 0.000 & 0.975 \\
$\mathrm{Ti}$ & 0.000 & 0.011 & 0.983 & 0.898 \\
$\mathrm{Fe}$ & 0.975 & 0.963 & 0.901 & 0.106 \\
$\mathrm{Mn}$ & 0.898 & 0.902 & 0.108 & 0.002 \\
$\mathrm{Mg}$ & 0.111 & 0.112 & 0.002 & 0.008 \\
$\mathrm{Ca}$ & 0.002 & 0.002 & 0.003 & 0.003 \\
$\mathrm{Na}$ & 0.017 & 0.000 & 0.000 & 0.002 \\
$\mathrm{~K}$ & 0.000 & 0.000 & 0.002 & 2.012 \\
$\mathrm{Total}$ & 0.000 & 0.000 & 2.008 & \\
\hline & 2.012 & 2.011 & & \\
\hline
\end{tabular}

